\title{
THE SOUTH AMERICAN LOW-LEVEL JET EXPERIMENT
}

by C. Vera, J. Baez, M. Douglas, C. B. Emmanuel, J. Marengo, J. Meitin, M. Nicolini, J. Nogues-Paegle, J. Paegle, O. Penalba, P. Salio, C. Saulo, M. A. Silva Dias, P. Silva Dias, and E. Zipser

A recent field campaign aimed at obtaining an improved temporal and spatial description of the tropospheric flow over central South America was essential for the validation, and improvement of, short- and long-term predictions in the region.

A continental-scale gyre (South Atlantic subtropical high) transports moisture westward from the tropical Atlantic Ocean to the Amazon

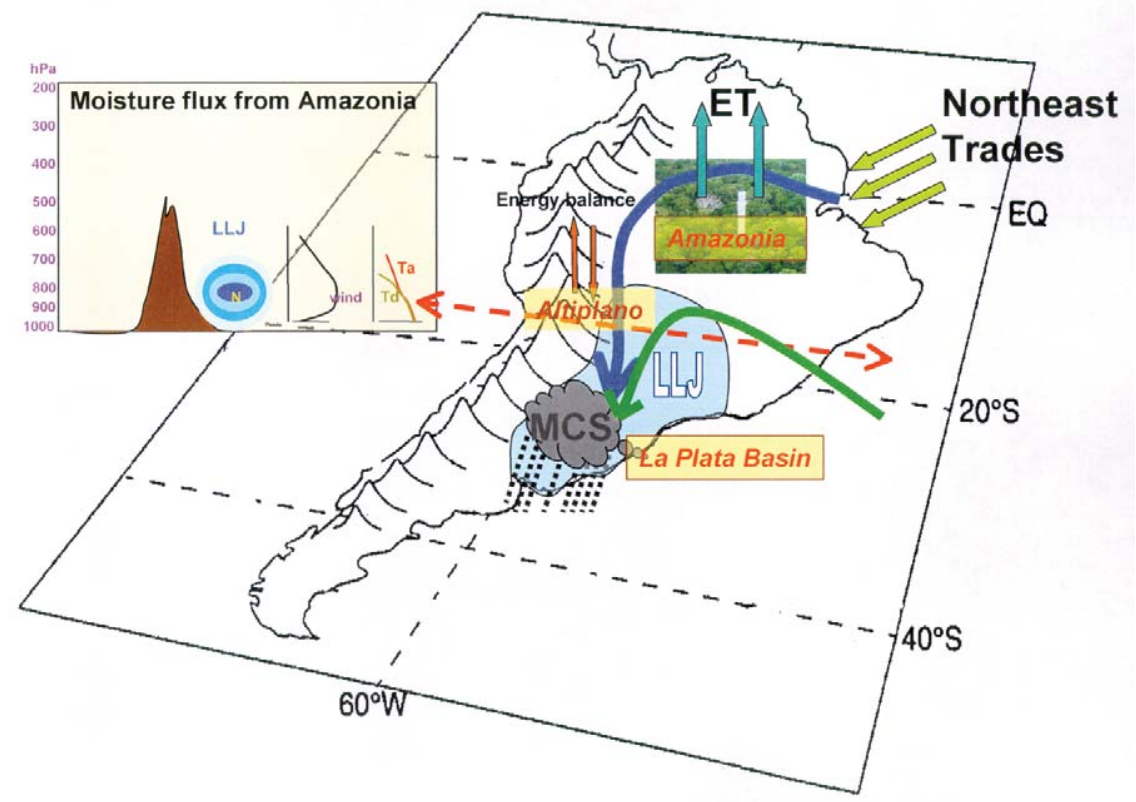

Fig. I. Schematic diagram of elements relevant to poleward moisture transport over South America. Blue and green arrows depict the moisture transport into the continent from the tropical and South Atlantic Ocean, respectively. The inset represents a vertical cross section of the northerly flow along the red dashed line displayed in the diagram, including wind and temperature profiles representative of the LLJ core. basin, and then southward toward the extratropics of South America (Fig. 1). A regional strengthening of this gyre to the east of the Andes Mountains has been called SALLJ (a list of acronyms and their expansions appears in Table 1 on p. 13), with the strongest winds being observed in Bolivia near Santa Cruz de la Sierra. SALLJ is a key feature of the continent's climate, transporting considerable moisture from the Amazon to the La Plata basins (Virji 1981; Paegle et al. 1987) (Fig. 2). The La Plata basin, located over central and subtropical South America (Fig. 1), drains a region similar in size to the Mississippi River basin, with the water cycles having a comparable magnitude. It is similar to the better-known Amazon River system in terms of its biological and habitat diversity, and far exceeds that system in its economic 

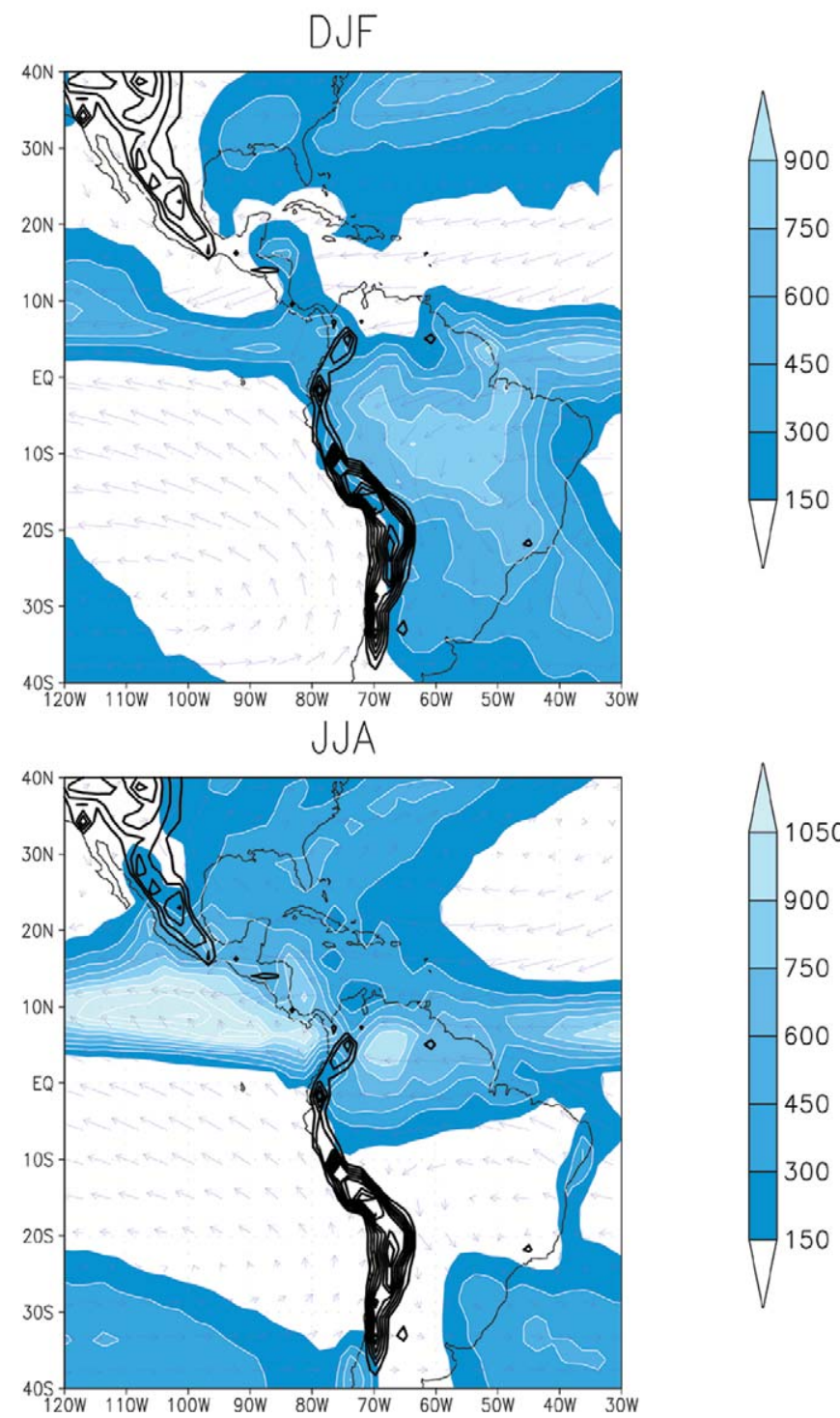

Fig. 2. Climatological mean annual precipitation [contour, from Xie and Arkin (1997)] and vertically averaged climatological mean moisture fluxes (arrows, from NCEP-NCAR reanalysis) for (a) DJF and (b) JJA. Contour interval is $150 \mathrm{~mm}$, arrow units: $\mathrm{kg}(\mathrm{m} \mathrm{s})^{-1}$, and altitude values of the topography higher than $1000 \mathrm{~m}$ are contoured in black. importance to southern and central South America in terms of hydroelectric and food production. The basin covers parts of five countries: Argentina, Bolivia, Brazil, Paraguay, and Uruguay; about $70 \%$ of the total GNP of the five countries combined is produced within the basin, which is also inhabited by about $50 \%$ of their combined population. Numerous hydroelectric plants provide energy to the region, and agriculture and livestock are among the region's most important resources.

The SALLJ maximum over Bolivia is present all year-round, due to the dynamical (rather, thermodynamical) modification that the Andes Mountains produce in the mean circulation (Byerle and Paegle 2002; Campetella and Vera 2002). Consequently, the seasonal cycle of rainfall over southeastern South America, south of $20^{\circ} \mathrm{S}$, is not characterized by a distinct warm rainy season. On the other hand, the low-level flow in tropical regions is clearly modulated during the summer by thermodynamic processes associated with precipitation either over the SACZ or southeastern South America regions (Berbery and Collini 2000).

The region is highly sensitive to natural climate variability, such as that associated with ENSO. Warm (cold) ENSO events
AFFILIATIONS: Vera, NicolinI, SALIO, AND SAULO-Centro de Investigaciones del Mar y la Atmósfera (CIMA)/CONICET Departamento de Cs. De la Atmósfera y los Océanos/Universidad de Buenos Aires, Buenos Aires, Argentina; BAEZ-Dirección de Meteorología e HidrologíaDINAC, Asunción, Paraguay; Douglas_-NOAA/NSSL, Norman, Oklahoma; EMmanuel AND MeITIN—UCAR/JOSS, Boulder, Colorado; Marengo-INPE/CPTEC, Cachoeira Paulista, Brazil; Nogues-Paegle, PAEGLE, AND ZIPSER - University of Utah, Salt Lake City, Utah; PenALBA-Departamento de Cs. De la Atmósfera y los Océanos/Universidad de Buenos Aires, Buenos Aires, Argentina; M. A. SILva DIAs-INPE/ CPTEC, Cachoeira Paulista, and University of Sao Paulo, Sao Paulo,
Brazil; P. SILVA DIAS—University of Sao Paulo, Sao Paulo, Brazil CORRESPONDING AUTHOR: Dr. Carolina Vera, CIMA, Pab. 2, 2do Piso, Ciudad Universitaria, (1428) Buenos Aires, Argentina E-mail: carolina@cima.fcen.uba.ar

The abstract for this article can be found in this issue, following the table of contents

DOI:10.II75/BAMS-87-I-63

In final form 6 September 2005

(C)2006 American Meteorological Society 
induce positive (negative) rainfall anomalies over southeastern South America with major impact on the hydrology of the La Plata basin (e.g. Ropelewski and Halpert 1987). In general, floods and droughts over the basin correlate with the intensity and positioning of the SALLJ, whose mesoscale cross-stream dimensions modulate the structure of summer and spring rains through the organization of MCSs at its exit region. The La Plata basin is in fact one of the regions of the world with the largest frequency of such systems (Nesbitt and Zipser 2003), and thus the MCS prediction has great practical significance. Poleward moisture penetration over South America is also strongly modulated on different time scales ranging from diurnal to interdecadal periods, suggesting the predictive potential of the low-level

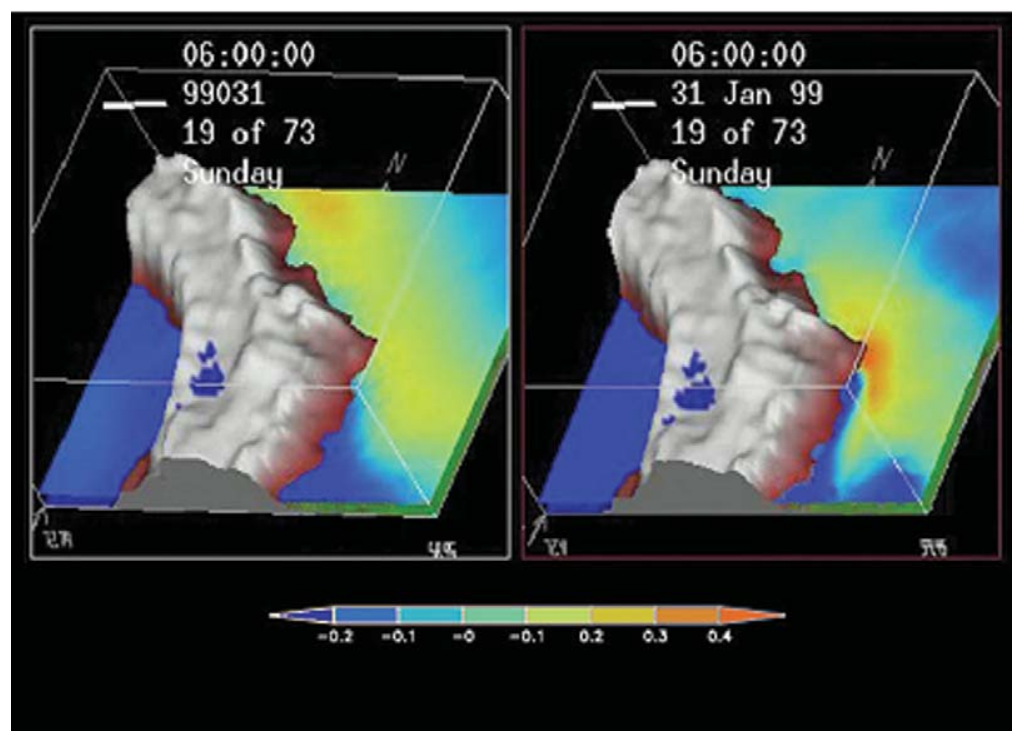

FIG. 3. Vertically integrated moisture transport from (left) a model with a resolution of $64 \mathrm{~km}$ and from (right) a nested model with a resolution of $16 \mathrm{~km}$. The same contour interval of $0.1 \mathrm{~kg} \mathrm{~m}^{-2} \mathrm{~s}^{-1}$ is used on both figures. It is evident that the higher-resolution model confines the LLJ and the associated moisture transport to a narrower strip along the Andes.

flow. Realization of this potential requires identification of the source of this variability both with respect to remote influences and regional forcings.

Bonner (1968) established certain criteria to define LLJs over the North American Great Plains, which has been applied to the South American case. These criteria are based on the magnitude of the wind and the vertical profile of the wind speed, such that the wind maximum has a jet-like profile. Studies based on the 4-times-a-day available NCEP-NCAR reanalysis (Marengo et al. 2004b), ERA (Salio et al. 2002), and 40-km-resolution ETA/CPTEC model forecast products (Saulo et al. 2000) suggest that South American LLJs are more frequent and intense between 0600 and 1200 UTC for the warm season north of $20^{\circ} \mathrm{S}$ near the core of the jet, shifting to 0000 and 0600 UTC when the maximum is found further south $\left(\sim 30^{\circ} \mathrm{S}\right)$. The few upper-air observations that are available since 1998 have localized the maximum of the wind between 1000 and 1600 m ASL in Santa Cruz de la Sierra (Douglas et al. 1999) with a lateral extension of about $500 \mathrm{~km}$. Numerical simulations of individual cases performed previous to the field campaign (Silva Dias et al. 2001) showed that the structure of the LLJ seems to be highly dependent on the horizontal resolution, and results indicate that the jet tends to be more confined to the slopes of the Andes as the resolution is increased (Fig. 3).

Regarding the possible mechanisms for SALLJ development, a number of them have been proposed as follows:

1) the deflection of the trade wind circulation that crosses the Amazon basin;

2) a purely local, topographically generated feature, driven by dry dynamics, but possibly modified by moist convection on the Andean slopes;

3) an externally forced feature, produced by variations in the pressure field in northern Argentina associated with transient perturbations in the westerlies;

4) propagation of low-level wind bursts from the North Atlantic toward the La Plata basin through the Amazon basin.

The SALLJ extends over some of the largest data voids in South America and routinely available datasets are not adequate to describe the SALLJ threedimensional structure and its diurnal cycle. Current operational observing systems do not resolve the SALLJ, and related diurnal precipitation cycles are seriously distorted in global data assimilation. Although the diurnal cycle should be particularly predictable because of its regularity, GCM simulations of related phenomena such as nocturnal precipitation and wind maxima are poor. Such deficiencies are not likely to be overcome without sufficient observations to calibrate 
model simulations of the full diurnal cycle. Although indirect estimates of low-level circulations are provided by satellite remote sensing techniques, these analyses have deficiencies and require evaluations with independent datasets. Better documentation of the horizontal and vertical structure of SALLJ and its relationship to convection is critical.

The VAMOS program, which is part of CLIVAR of WCRP, developed a SALLJ project aimed at understanding the role of SALLJ in moisture and energy exchange between the Tropics and extratropics and related aspects of regional hydrology, climate, and climate variability. The SALLJ project belongs programatically within VAMOS/MESA (information online at www.joss.ucar.edu/mesa). In particular, in order to attempt to resolve the uncertainties related to the SALLJ, the VAMOS community organized and carried out a field campaign, SALLJEX, between 15 November 2002 and 15 February 2003. Special in situ measurements were made in Bolivia, Paraguay, central and northern Argentina, and western Brazil, to fill observational gaps and to describe many aspects of SALLJ. SALLJEX observations are essential for validation of numerical simulation studies of the structure of the jet and the associated precipitation and its variability. Scientists, collaborators, students, and local volunteers from Argentina, Brazil, Bolivia, Paraguay, Chile, Uruguay, Peru, and the United States participated in SALLJEX activities in an unprecedented way. SALLJEX is the first WCRP/CLIVAR international campaign carried out in South America.

A full description of the scientific implementation plan for SALLJ is included in the document on ALLS, which is available online at www.clivar.org/organization/vamos/. The main scientific questions and observing systems that were deployed during SALLJEX are described below.

IMPLEMENTATION OF SALLJEX. One of the goals of SALLJEX is to reduce the uncertainty in estimating the daily (and longer time scale) characteristics of the tropospheric flow over a large region of South America that is currently lacking a sufficiently dense sounding network. Accurate atmospheric estimates are needed to quantify the variability of the LLJ over different spatial and temporal scales, as well as to describe the spatial variability of the diurnal cycle of the lower- and middle-tropospheric wind field.

An upper-air network, including radiosonde and pilot balloon sites, was established during SALLJEX to reduce the upper-air observational gaps existing in the region (Fig. 4). The network included pilot balloon sites previously established by PACS-SONET (information available online at www.nssl.noaa. gov/projects/pacs) that were already operating in the region. The BOP of the network extended from 15 November 2002 to 15 February 2003 and consisted of one RAOBS at 0600 UTC and two PAOBSs at 0600 and 2100 UTC. Within the BOP, an SOP took place between 6 January and 15 February 2003. RAOBS were launched twice daily (0600 and 2100 UTC), while PAOBS were made 4-times daily in Argentina, Bolivia, and Paraguay. In Brazil, four RAOBS were made each day at SALLJEX sites. IOPs had a higher observational frequency with three or four RAOBSs and/or eight pilot balloon observations per day at selected sites along the LLJ axis.

Knowledge of detailed horizontal variations in the LLJ structure is important for the validation of fine mesoscale model simulations of the jet, especially along the topographic gradient immediately east of the Andes. The inherent uncertainties associated with larger-scale analyses (such as the NCEP reanalysis) also mandate such observations to identify possible systematic errors of the analyzed horizontal moisture fluxes. In this context, the flight missions of the Lockheed WP-3D Orion aircraft owned by NOAA (P-3) were an essential component of SALLJEX in providing a detailed representation of the mesoscale structure of the LLJ east of the Andes and useful information for the study of the NAL, MCSs, and their relationship with SALLJ. The NOAA P-3 is one of the two world's premier research aircrafts, and it participated in a wide variety of national and international meteorological, oceanographic, and environmental research programs in addition to its widely known use in hurricane research and reconnaissance. It is equipped with an unprecedented variety of scientific instrumentation, radars, and recording systems for both in situ and remote sensing measurements of the atmosphere, the Earth, and its environment. Further information about the NOAA P-3 is available online at www.aoc.noaa.gov/aircraft_lockheed.htm.

Multinational field experiments require a variety of complex arrangements that must be made from months to years in advance, and in particular, the operation of the NOAA P-3 required the necessary flight permits to execute research flights in support of SALLJEX scientific objectives. Consequently, permits were secured for flights over Bolivia, Paraguay, Argentina, and Chile. The NOAA P-3 base of operations was also chosen to be based in Santa Cruz de la Sierra, carrying out its research missions from Viru Viru International Airport.

The SALLJEX Project Office established a base of operations in Santa Cruz de la Sierra (identified 
as "Santa Cruz" in Fig. 4) in order to coordinate the flights and the IOP phases. Most of the principal investigators participating in SALLJEX were present there during a 6-week period when the intensive observations were made over the SALLJEX domain. Daily meetings were conducted during the entire period; the meetings started at $1400 \mathrm{LST}$, with a decision for the next day's operations accomplished no later than 1600 LST. The meeting's agenda consisted of a presentation of the forecast for the next 24-48 h, as well as other meteorological products, model outputs and analyses, and satellite imagery. Regional, real-time model simulations provided by researchers within organizations in South America and the United States were used for guidance in planning IOPs and flights. Real-time comparisons between model results and observations were routinely made. In addition, there were status reports pertaining to aircraft research systems, land meteorological sites, etc. After these discussions, the attending SWG members and other investigators deliberated the potential mode of operations for the next $24 \mathrm{~h}$, sometimes considering the 48-72-h period as well.

NOAA P-3 deployment went as planned, with 13 research missions flown between 11 January and 8 February, for a total of 99 research hours (Emmanuel et al. 2004). Figure 5 summarizes SALLJEX flights, as well as their motivations. Fortuitously, the weather during the aircraft program allowed for most of the planned flights to be carried out. There were only minor deviations from the planned allocation of flights to the various objectives, as forced by the weather. In addition to eight flights for the LLJ structure, there was one complete MCS mission and two partial MCS missions-one southerly (cold front) jet, one northwestern Argentina low mission, and one mission to the east Pacific, which also sampled an undisturbed day on the Altiplano, covering similar tracks about $5 \mathrm{~h}$ apart. The numerical studies of Garreaud (1999) indicated the importance of the largescale flow intensifying afternoon moisture transport on the eastern slopes of the Andes, allowing moisture from the Bolivian lowlands to reach the Altiplano and initiate afternoon convection. The majority of the LLJ flights were carried out in a "porpoising" mode,

\section{SALLJEX Upper Air Network During the SOP}

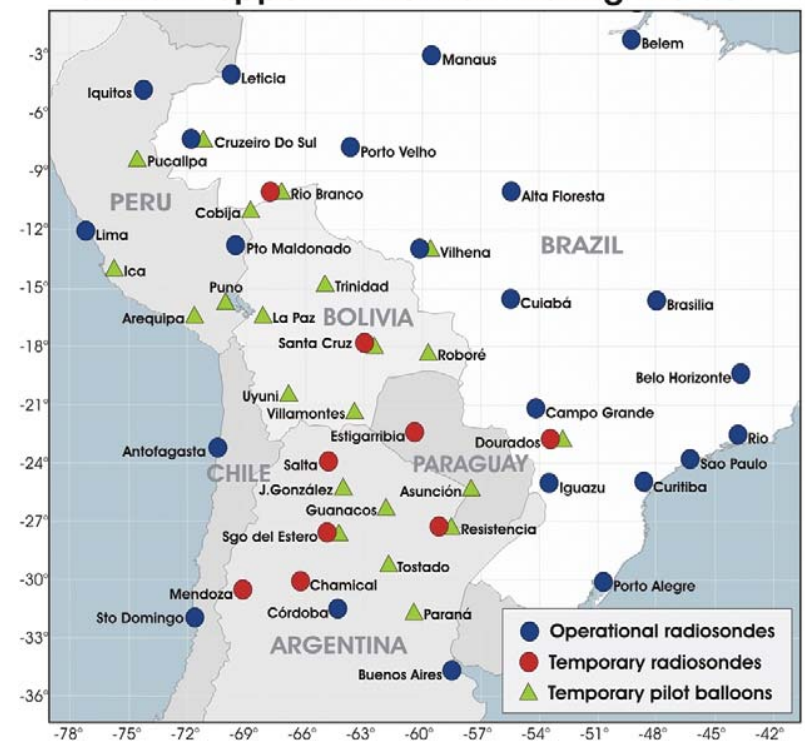

FIG. 4. Radiosonde and pilot balloon networks of SALLJEX.

which involved almost continuously ascending and descending between $300 \mathrm{~m}$ and about $3000 \mathrm{~m}$ AGL, occasionally as high as $4000-5000 \mathrm{~m}$ (e.g., Fig. 8b). This mode was designed for mapping out essential features of the horizontal and vertical structure of the LLJ.

One objective of SALLJEX was to determine the relationship between fluctuations in the SALLJ and precipitation over the region. To do this a dense rain gauge network was considered desirable. Additional rainfall observations were also considered to be important for providing ground truth estimates to help determine the accuracy of satellite-rainfall estimates over the region, as well as for comparison with various numerical simulations of rainfall

\begin{tabular}{|l|l|}
\hline $\begin{array}{c}\text { Flight } \\
\text { dates }\end{array}$ & \multicolumn{1}{|c|}{ Flight type } \\
\hline Jan 11 & LLJ-Test aircraft operating procedures \\
\hline Jan 15 & LLJ-Successful in obtaining many profiles of a weak jet \\
\hline Jan 17 & LLJ-Jet details near the topography NW of Santa Cruz \\
\hline Jan 18 & LLJ-Cold Front-MCS \\
\hline Jan 21 & LLJ-No significant deep convection along flight track \\
\hline Jan 22 & LLJ-MCS genesis \\
\hline Jan 24 & Cold Surge \\
\hline Jan 28 & Altiplano-South Pacific diurnal variations of the ML \\
\hline Feb 1 & Northwestern Argentina heat low \\
\hline Feb 4 & LLJ-Northern Argentina. Samples of Convective cells. \\
\hline Feb 6 & LLJ-Southern Bolivia and Western Paraguay. \\
\hline Feb 7 & LLJ-Observed jet with "classical" distribution \\
\hline Feb 8 & LLJ-MCS. \\
\hline
\end{tabular}

FIG. 5. List of NOAA P-3 missions during SALLJEX, including a picture of the Andes taken from the aircraft during one of the missions. 
in the region. Approximately 1200 simple rain gauges were installed for SALLJEX in Argentina, Paraguay, Bolivia, and Peru (Fig. 6). The installations of around 250 gauges were largely successful in Argentina, and were merged with ones that were already installed, but whose data had not been easily available ( 1500 stations) because they were owned by different local institutions. In Paraguay, SALLJEX installation activities ( 300 gauges) uncovered many additional rain gauges operated by the agricultural sector ( 250 stations). In Bolivia there were coordination difficulties with the rain gauge installation, which were aggravated by transport strikes and road closures. Nevertheless, more than 220 gauges have been installed in military outposts, with another 40 in the vicinity of Santa Cruz de la Sierra. In Peru, rain gauge installation ( 340 stations) was split among IGP and SENAMHI and was fully successful. SALLJEX activities in Brazil were concentrated on the installation of two dense rain gauge networks of 20 and 40 rain gauges, re-

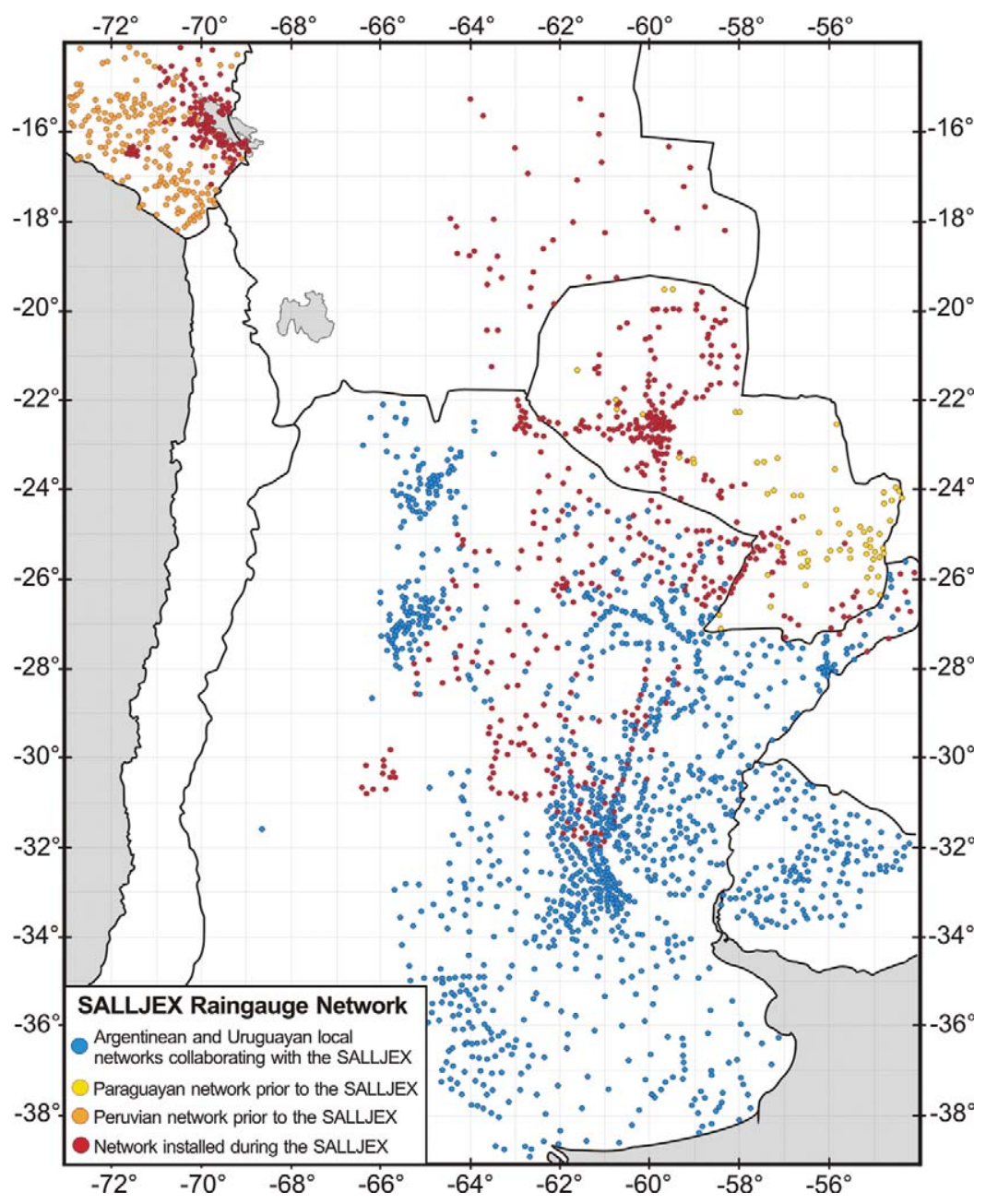

FIg. 6. SALLJEX rain gauge network. of 1958-2000. spectively, that provided rainfall data with a 5 -min resolution (Marengo et al. 2004a).

SOME INITIAL RESULTS. To quantify the LLJ variability over different spatial scales was one of the main objectives of SALLJEX. During the January-February 2003 period, four LLJ episodes [identified using the Bonner (1968) criteria] were detected in Santa Cruz de la Sierra (Fig. 7) using the NCEP reanalyses, and later confirmed by the radiosonde observations collected in Santa Cruz de la Sierra. The reduced number of LLJ episodes identified during this particular summer, defined as a weak ENSO warm event, agrees with the results of Marengo et al. (2004b), which do not show a clear signal between the occurrence of ENSO events and the frequency and intensity of LLJ events in Santa Cruz de la Sierra as described from NCEP reanalyses over the period

SALLJEX missions were also intended to increase our understanding of the three-dimensional structure of SALLJ, as well as its diurnal cycle. Recently, Nicolini et al. (2004b) summarized an improved description of the lowlevel circulation provided by the SALLJEX-enhanced upper-air network. Observations made during the NOAA P-3 flight on 6 February 2003 show the horizontal and vertical structure of the low-level flow, mainly characterized by a moderately intense SALLJ located over Bolivia and western Paraguay with a maximum wind speed of about $25 \mathrm{~m} \mathrm{~s}^{-1}$ in the 800-700-hPa layer (Fig. 8). Preliminary results indicate that winds derived from RAMS model simulations accurately describe the general northwest flow and the position of the maximum, but the intensity is underestimated. During SALLJEX, the altitude of the speed maximum was as low as $500 \mathrm{~m}$ and as high as $3 \mathrm{~km}$ within the domain with a tendency to rise during daytime hours, consistent with mixed-layer growth (Fig. 9). The expected counterclockwise diurnal rotation of the wind was observed during the SALLJEX period, although local 
differences were found (Nicolini et al. 2004b). Both the low-level jet signal as well as the amplitude of the wind diurnal cycle are stronger in the LLJ cases penetrating further south into the subtropics (CJEs) than those more confined to the region of the climatological mean wind speed maximum (NCJEs; Nicolini et al. 2002). Nevertheless, despite the improvement in temporal resolution and the efforts that have been made to document the nocturnal part of the wind cycle (mostly at 0600 UTC), it is still difficult to determine from SALLJEX data the exact timing of the wind speed maximum.

In order to make progresses in the understanding and simulation of the leading mechanisms responsible for the LLJ intensification, the nature of the NAL and its interaction with SALLJ was another key scientific issue proposed to be addressed by SALLJEX. The NAL is a thermal-orographic low pressure system commonly observed near the Andean eastern slopes, with a center located approximately at $30^{\circ} \mathrm{S}$, $67^{\circ} \mathrm{W}$ (Lichtenstein 1980). Previous modeling studies (Seluchi et al. 2003) had shown that the summer NAL has a significant diurnal cycle, and its existence is mostly explained by the sustained surface warming maintained by the positive radiative surface balance resulting from the circulation of the previous clear skies characterizing the area. Several studies based on reanalyses (Salio et al. 2002; Nicolini et al. 2002) have previously shown that the strengthening of the NAL seems to play a role in the southward intensification of SALLJ into the subtropics. Modeling studies (Saulo et al. 2004b) show that the poleward extent of SALLJ is in geostrophic balance with the NAL, reinforcing the idea that a better understanding of processes leading to NAL deepening will also aid in the explanation of SALLJ timing and intensity. Because no operational upper-air data are available over the NAL region, the description of the observational basis of the NAL and its interaction with the SALLJ had not been possible before SALLJEX. One of the NOAA P-3 flight missions was dedicated to the observation of the NAL. Figure 10 shows a streamline analysis at $700 \mathrm{hPa}$ based on the NOAA P-3 wind observations made on 1 February 2003. The circulation

\section{SALLEX OUTREACH}

SALLJEX provided an exceptional learning opportunity for students at many levels and technicians at different network locations. Also, SALLJEX promoted the interaction between the research centers involved in the experiment and many different local institutions acting all over the countries of the region. Students from Universities in Argentina, Brazil and the United States, as well as local people collaborated with the SALLJEX scientists, installing rain gauges, taking observations, collecting data, attending weather briefing and planning meetings, among other activities. Application of the SALLJEX experience has already been shared to the classroom. Mark Eastburn, an elementary school teacher at Johnson Park School in New Jersey and Ana Maria Varela, a high school teacher at the Nicolas Copernico High School in Buenos Aires, Argentina, participated in SALLJEX through the NOAA/OGP-NSF program "Teachers in the Field". While on this adventure, Mark and Ana Maria hosted several live web broadcasts, taught their classes, wrote lessons plans, maintained daily logs, took photographs, interviewed scientists, and engaged in a dialogue with other teachers and students, as well as the general public around the world. Further information about this program is available at www.ogp. noaa.gov/salljex/index.htm.

measured with the NOAA P-3 confirmed that the thermal pattern supports a regional circulation with strong low-level winds on its eastern branch, even at $700 \mathrm{hPa}$. Skew $T$ diagrams derived from the flights indicate a deep mixed layer that reaches $670 \mathrm{hPa}$ over the warmer surfaces (Fig. 11). The depth of the mixed layer increases toward the low-level pressure center. The unique stratification of this system has been identified for the first time, and it is in qualita-

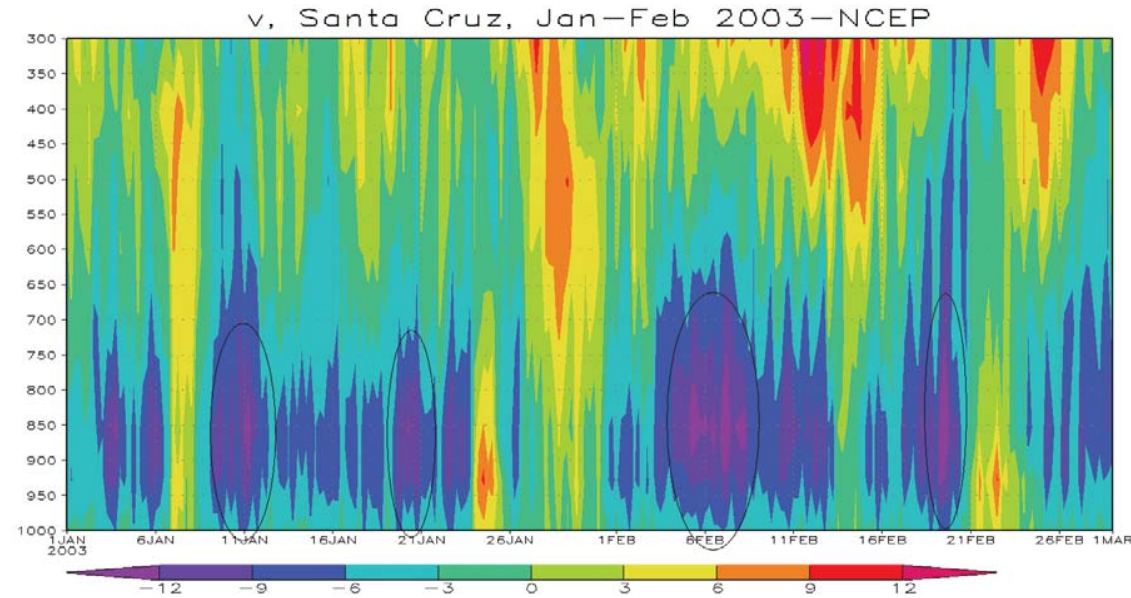

FIG. 7. Episodes of LLJ detected in Santa Cruz de la Sierra during the Jan-Feb 2003 period using the NCEP-NCAR reanalyses as depicted from Hovmoeller diagram of the vertical profile of meridional wind. Contour interval is $3 \mathrm{~m} \mathrm{~s}^{-1}$. 
tive agreement with what was expected from previous studies, although it is more intense (Saulo et al. 2004a).

The relationship between the MCS and LLJ was also a main goal of SALLJEX. In particular, how the LLJ contributes to MCS development and what the synergism is between both entities were a couple of the questions planned on being addressed with the experiment. Zipser et al. (2004) used satellite-derived

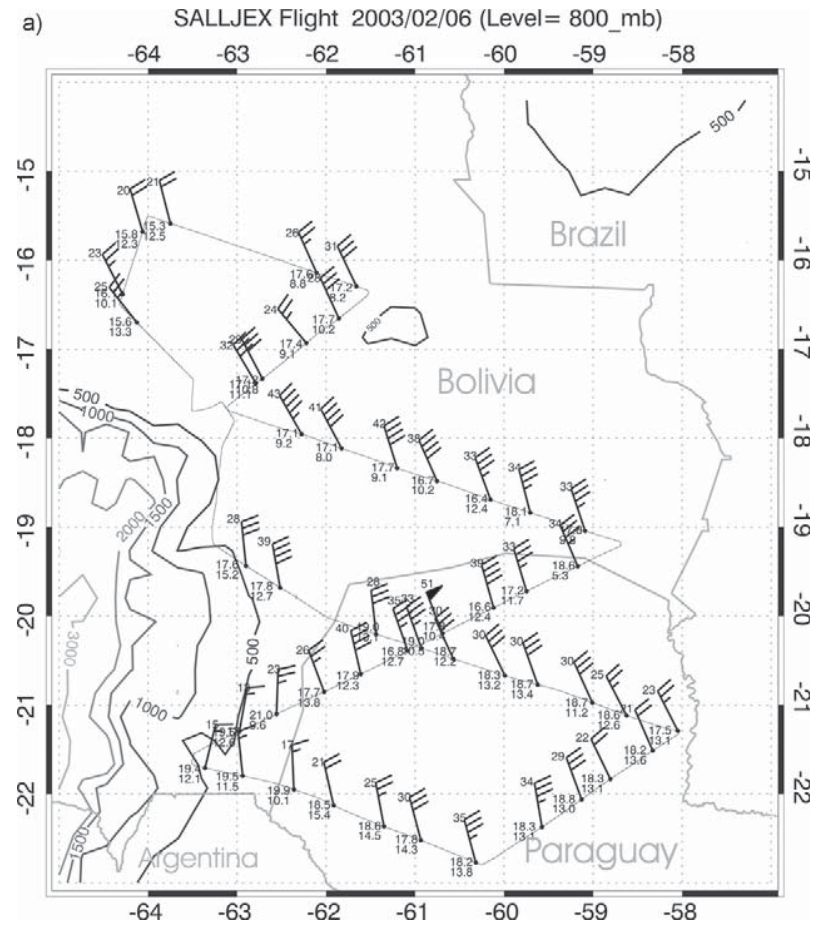

b)

2003/02/06 (15:0-16:20) Wind Magnitud [m/s]

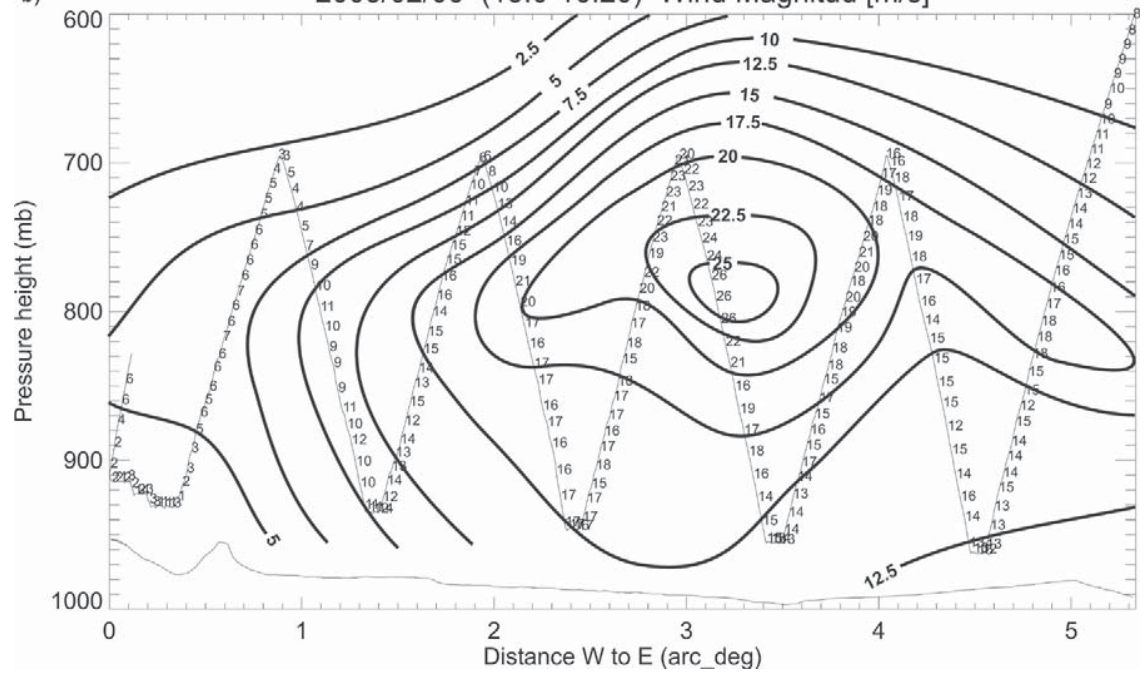

FIG. 8. (a) NOAA P-3 flight trajectory and wind field (one full wind barb $=10 \mathrm{kt}$ ) plotted at $800 \mathrm{hPa}$ on $6 \mathrm{Feb} 2003$, (b) isotach analysis $\left(\mathrm{m} \mathrm{s}^{-1}\right)$ in vertical cross section along northeast-southwest transect (that goes from $19.2^{\circ} \mathrm{S}, 58.7^{\circ} \mathrm{W}$ to $21.5^{\circ} \mathrm{S}, 63.5^{\circ} \mathrm{W}$ ) and aircraft ascents and descents in the $1500-1620$ UTC time interval. Contour interval is $2.5 \mathrm{~m} \mathrm{~s}^{-1}$.
IR brightness temperature to determine the position and stage of every MCS during the SALLJEX period. SALLJEX has a total of 112 MCS cases over the continental region southward of $20^{\circ} \mathrm{S}$ with an average lifetime of $11 \mathrm{~h}$. The mature stage of the systems peaks at two principal times-one very well defined frequency maximum in the afternoon and the other during the night and early morning. The nighttime maximum is mostly located west of $55^{\circ} \mathrm{W}$, while the afternoon maximum is over the continental SACZ area. Nicolini et al. (2004a) found that MCSs over Paraguay develop during NCJEs. On the other hand, MCSs over Argentina, southern Brazil, and Uruguay are mostly nocturnal, achieve their mature stage within CJEs, and, in around $70 \%$ of the cases, attain their maximum extent in phase with the LLJ maximum. The Chaco jet thermodynamic and wind field structure enhances the convective instability by transporting heat and moisture over the whole region.

A particularly interesting MCS occurred during a SALLJ day (22 January). The NOAA P-3 observations were almost ideally located in space and time to describe the explosively growing and mature stage of this large and intense MCS. A combination of a good forecast with good organization and planning made this mission successful. The early stages were dominated by strong convective cells, well documented by the NOAA P-3's Doppler radar (Fig. 12). The cells reached at least $19 \mathrm{~km}$ ASL, attaining vertical velocities well in excess of $30 \mathrm{~m}$ $\mathrm{s}^{-1}$. The radar data suggest that during the early and mature stages, the precipitation efficiency may have been rather low.

The impact of an enhanced observing network in the SALLJEX area is a major challenge that may lead to improvement of models, data assimilation procedures, and better use of remote-sensing products over continents. SALLJEX has led to systematic model intercomparisons for the first time over the region, which provided useful hints for model and forecast development, showing also the inability of global models to capture impor- 

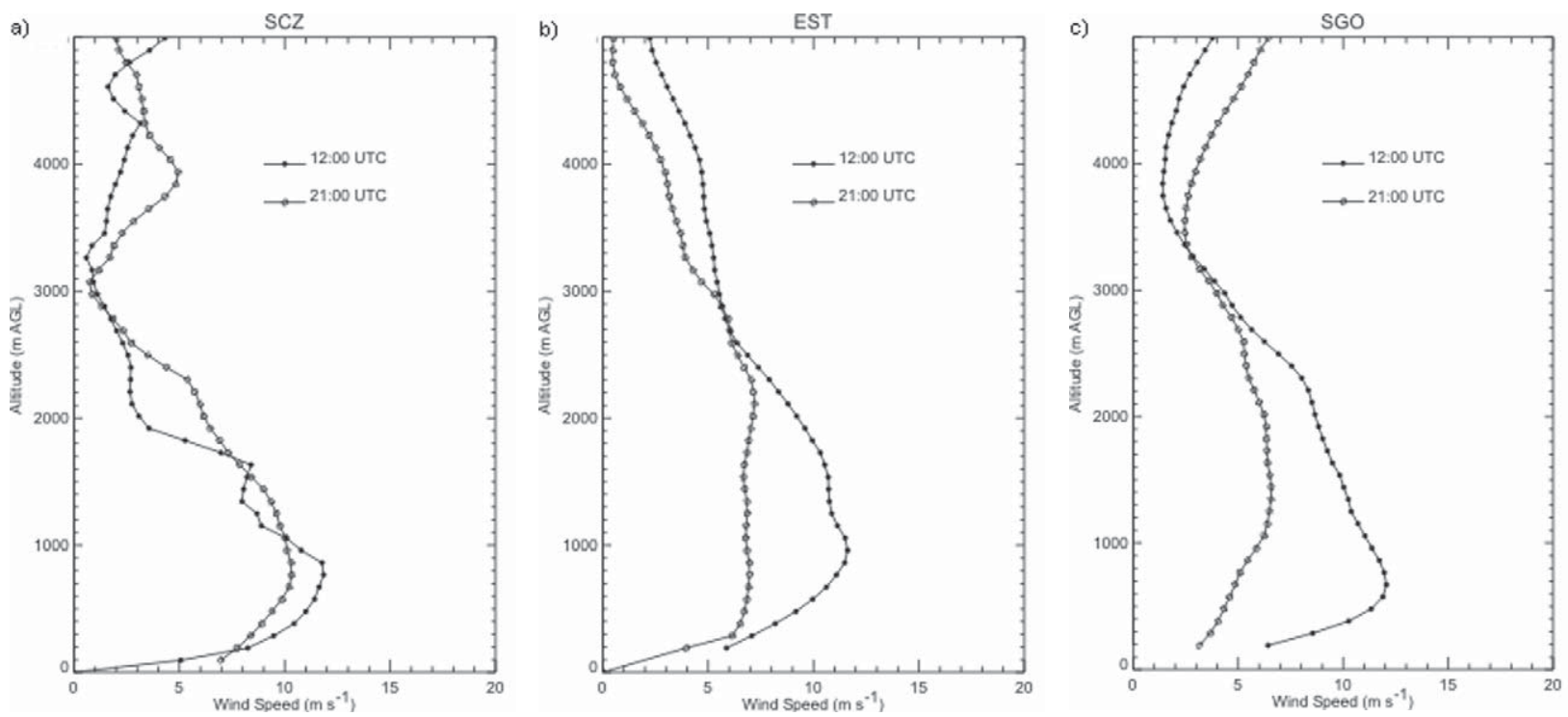

FIG. 9. Mean vertical profile of meridional wind at I200 and 2100 UTC in (a) Santa Cruz de la Sierra, (b) Estigarribia, Paraguay, and (c) Santiago del Estero, Argentina. Means were calculated over the times with LLJ events (as defined by Bonner 1968) identified from the SALLJEX period. Locations of the sites are displayed in Fig. 4.

tant details of regional circulations. A sample of recent studies focused upon the SALLJEX domain is summarized by Paegle et al. (2004). Also, a systematic intercomparison of regional models for a particularly active MCS has been initiated and includes versions of the ETA, RAMS, and MM5 run at institutions in South America and the United States, as well as the global CPTEC model (information available online at www.saljex.at.fcen.uba.ar). A key aspect of the research is to assess the degree of dispersion of forecasts generated with identical initial and lateral boundary conditions, and very similar domain and horizontal resolution through the simulation of an MCS event occurred during SALLJEX (Fig. 13a). There are several hypothesized reasons for the poor model performance for this case, including inadequate boundary data, inadequate initial data, poor model parameterizations, and inherent predictability limits. At the highest resolution (about $20 \mathrm{~km}$ ) models predict large amounts of precipitation (Fig. 13b), but most do not adequately reflect the precipitation associated with the MCS (Fig. 13a), and individual forecasts display high vari-

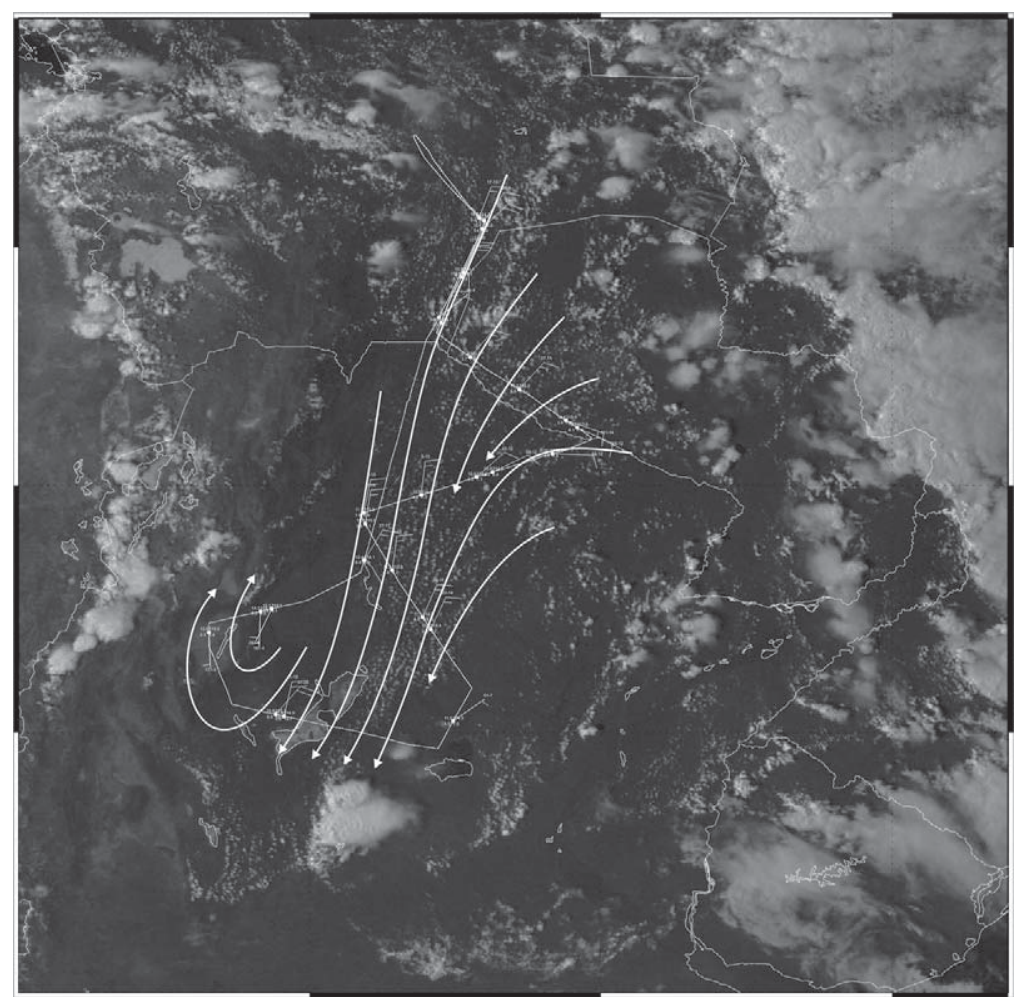

FIG. 10. First observational description of the spatial structure of the northwestern Argentinean low through streamlines and wind barbs at $700 \mathrm{hPa}$ (white) derived from NOAA P-3 soundings and plotted over the visible GOES image corresponding to 1945 UTC. The country borders are depicted in gray.

ability in areas of large precipitation. It is likely that much of the forecast variation reflects variability in model physical parameterizations, because all models 


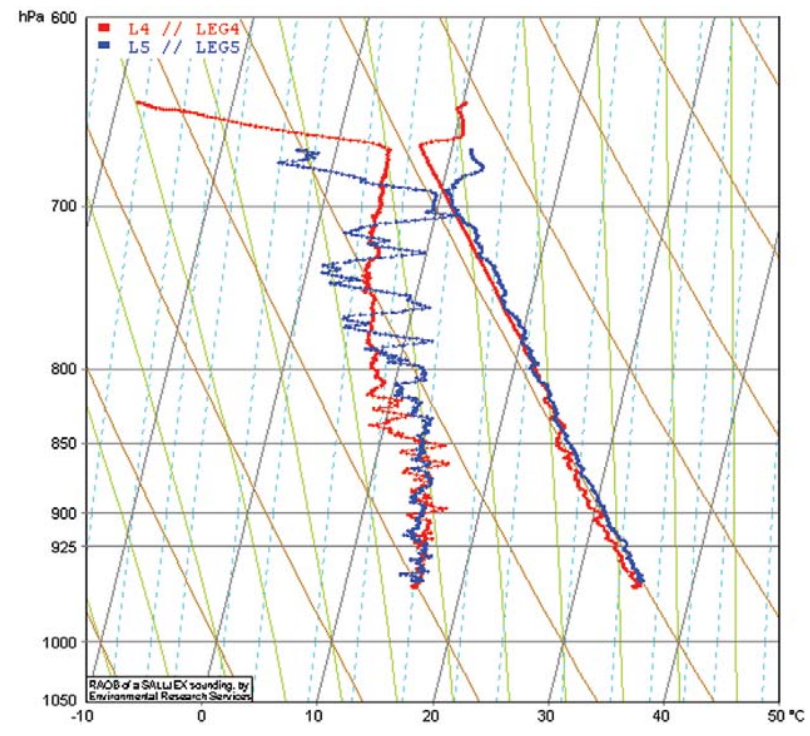

FIG. II. Skew T-logp diagram derived from NOAA P-3 sounding in the vicinity of the NAL core.

use the same initial and lateral boundary conditions. The poorly predicted MCS may also be due to errors of the initial-state specification, which did not have the benefit of SALLJEX observations.

Ongoing research utilizes the special SALLJEX observations in data assimilation systems. This effort has already begun at CPTEC and is planned in other research centers. Cavalcanti and Herdies (2004) used the PSAS and ran it with the CPTEC atmospheric GCM (T126, L28), both with and without SALLJEX data (Fig. 14). Preliminary results show some improvement in the simulation of the moisture transport along the LLJ, which was originally underestimated (Cavalcanti et al. 2002). In particular, the meridional wind profile observed at Santa Cruz de la Sierra during the LLJ episode of 21 January 2003 exhibits a low-level wind maximum of $16 \mathrm{~m} \mathrm{~s}^{-1}$, which is significantly larger than that simulated by the NO-SALLJEX run $\left(8 \mathrm{~m} \mathrm{~s}^{-1}\right)$, while the low-level wind maximum obtained from the model run with assimilated SALLJEX data is $13 \mathrm{~m} \mathrm{~s}^{-1}$ (Fig. 14b). The corresponding cross section of the meridional moisture transport along $17.5^{\circ} \mathrm{S}$ (which is roughly the location of Santa Cruz de la Sierra) shows that model estimates based on the SALLJEX data-assimilated fields exhibit larger moisture transport values (Fig. 14d) than those estimates obtained without assimilating SALLJEX data (Fig. 14c).

CONCLUSIONS. The first main phase of SALLJEX, which is the field data collection, is almost complete. Data analysis is currently well in progress with several ongoing key topics. A number of tentative conclusions can be summarized as follows:

1) The vertical distribution of the low-level wind measured during SALLJEX over tropical and subtropical South America provides observational evidence of the SALLJ and it allows for determination of the ability of models to simulate the SALLJ spatial structure.

2) Open questions still remain regarding the diurnal
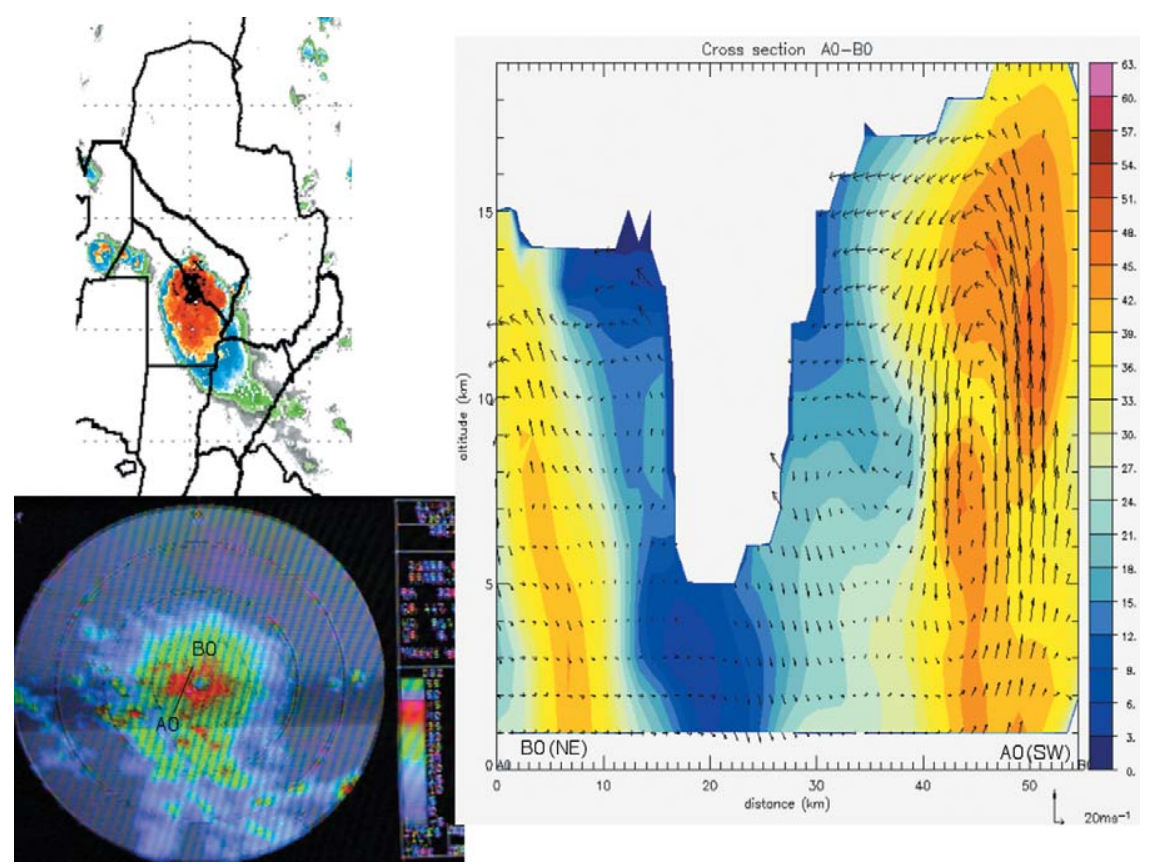

Fig. I2. (top left) Infrared satellite image at 2130 UTC 22 Jan 2003, with the location of the aircraft at 2145 UTC given by the $X$ on the north edge of the system. (bottom left) Plan view (belly) radar image from the NOAA P-3 at 2I45 UTC showing scattered strong echoes from individual storms (embedded in extensive surface clutter). The cross section from A0-BO from the NOAA P-3 (tail) Doppler radar goes through one of the rotating storms with updrafts in excess of $30 \mathrm{~m} \mathrm{~s}^{-1}$ and 35-dBZ echoes extending above $18 \mathrm{~km}$, or $4 \mathrm{~km}$ above the tropopause. The Doppler wind analysis is preliminary. Wind reference arrow is $20 \mathrm{~m} \mathrm{~s}^{-1}$ and shading interval for reflectivity is $3 \mathrm{dBZ}$. 
cycle of the SALLJ as well as of the associated precipitation. While the former was somewhat captured by SALLJEX data, the diurnal variability of rainfall was not measured by the gauge network.

3) NOAA P-3 data provided an unprecedented description of the structure of the NAL and its relationship with SALLJ, although the lack of upper-air data seriously limits observational study data over the NAL region.

4) The incursion of moisture transport from Bolivian lowlands westward into the southern portion of the Altiplano, responsible for driving convection over that particular region, was confirmed.

5) MCS development over subtropical South America has been described, at least for several SALLJEX cases.

SALLJEX represents an important start to study and better understand SALLJ and its role in shaping the climatic characteristics of South America. SALLJEX and its associated research agenda have, however, already revealed a number of important issues. Future research will utilize special SALLJEX observations in data assimilation systems. Preliminary results indicate the significant impact of SALLJEX observations upon a case study as well as improvement in the precipitation structure of an MCS in northern Argentina. Model experiments will focus upon the origin and maintenance of the SALLJ, and study a variety of mechanisms, including the topographic impact on trade winds, orographic effect in the absence of latent heating, impact of latent heat release upon the LLJ, impact of surface thermal heating relative to upper-level forcing associated with transient perturbations

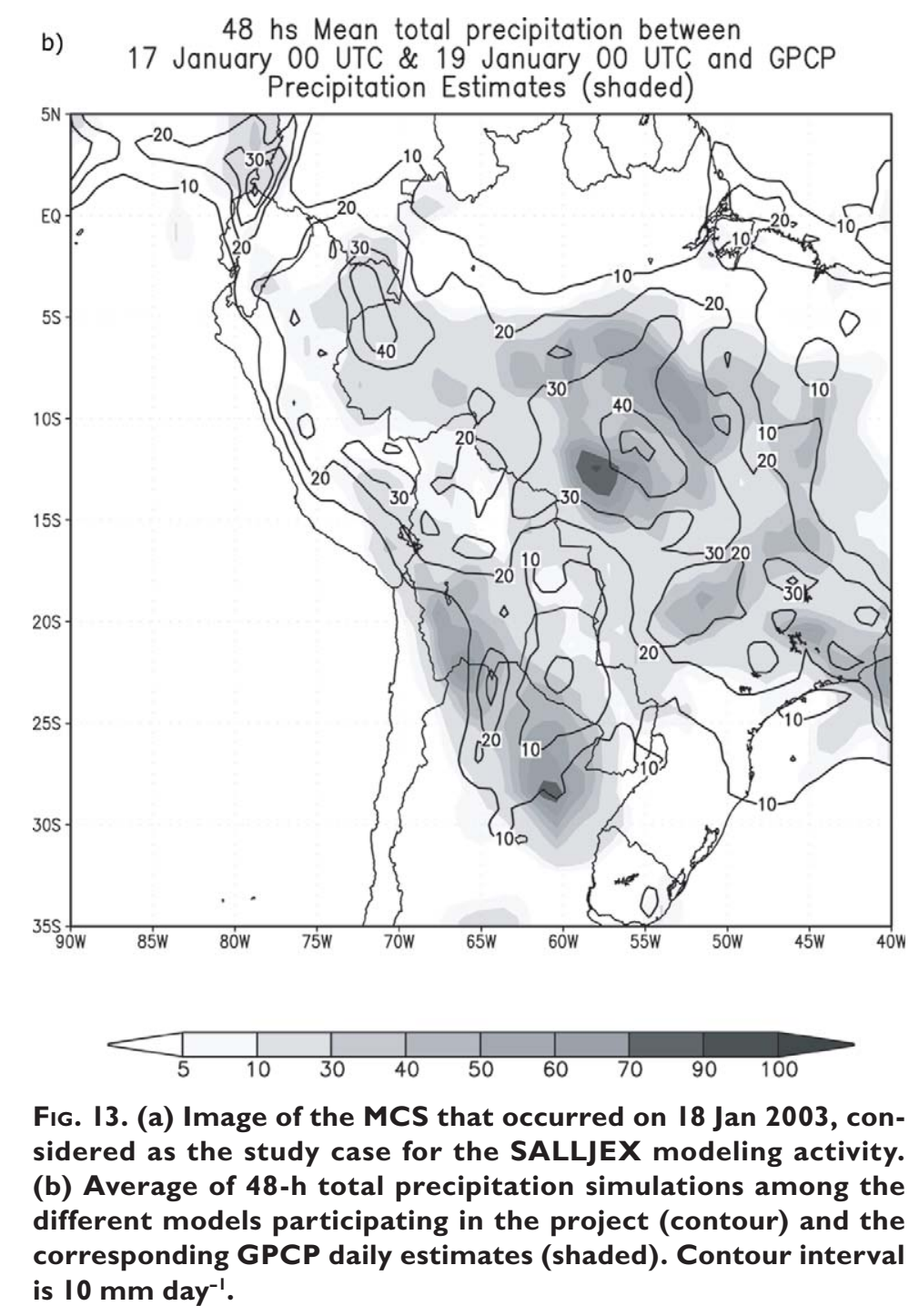




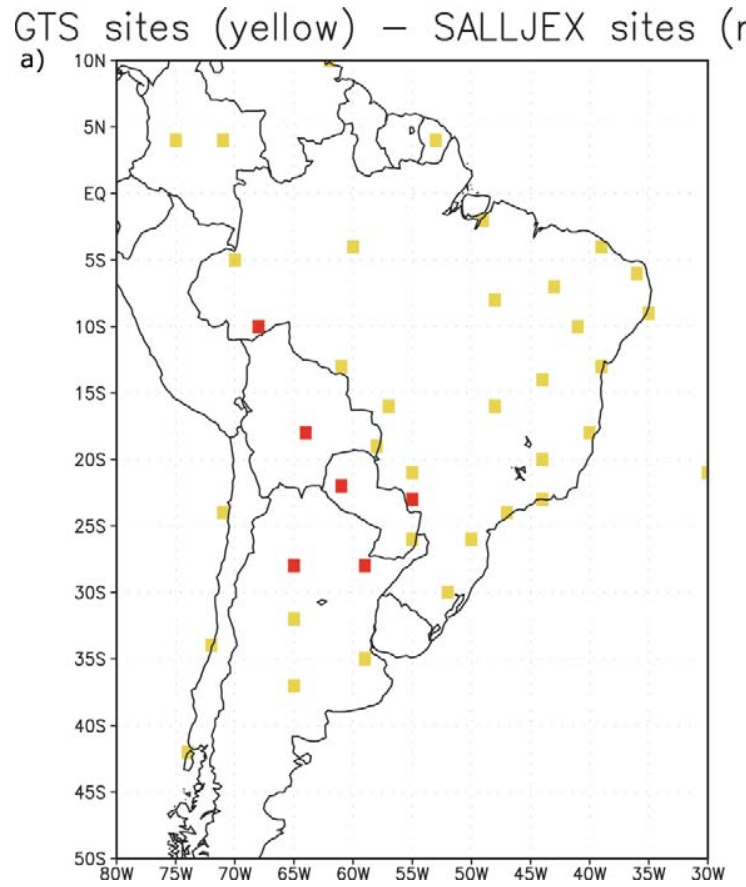

c) $v q(\mathrm{~m} / \mathrm{s} * \mathrm{~g} / \mathrm{kg})-\mathrm{T} 126 \mathrm{~L} 28-\operatorname{noSALLJEX}(18 \mathrm{~S}-62 \mathrm{~W})$

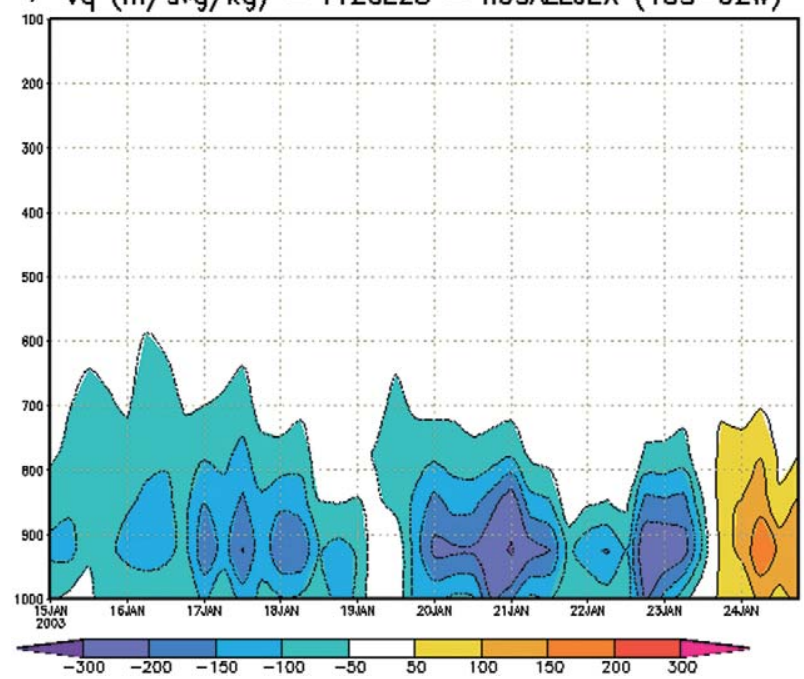

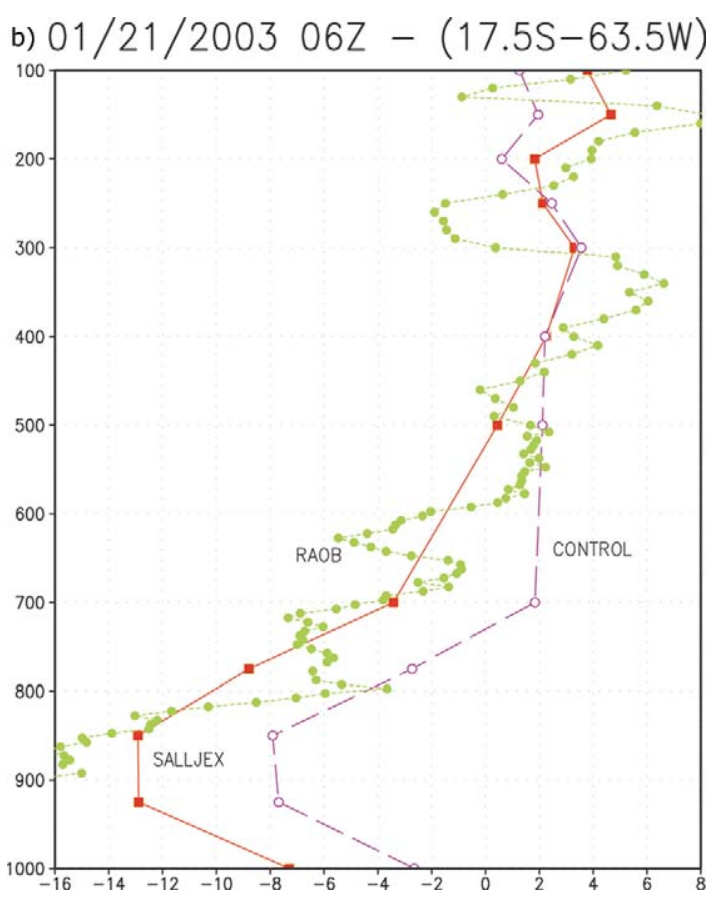

d) $\quad v q(\mathrm{~m} / \mathrm{s} * \mathrm{~g} / \mathrm{kg})-\mathrm{T} 126 \mathrm{~L} 28-$ SALLJEX $(18 \mathrm{~S}-62 \mathrm{~W})$

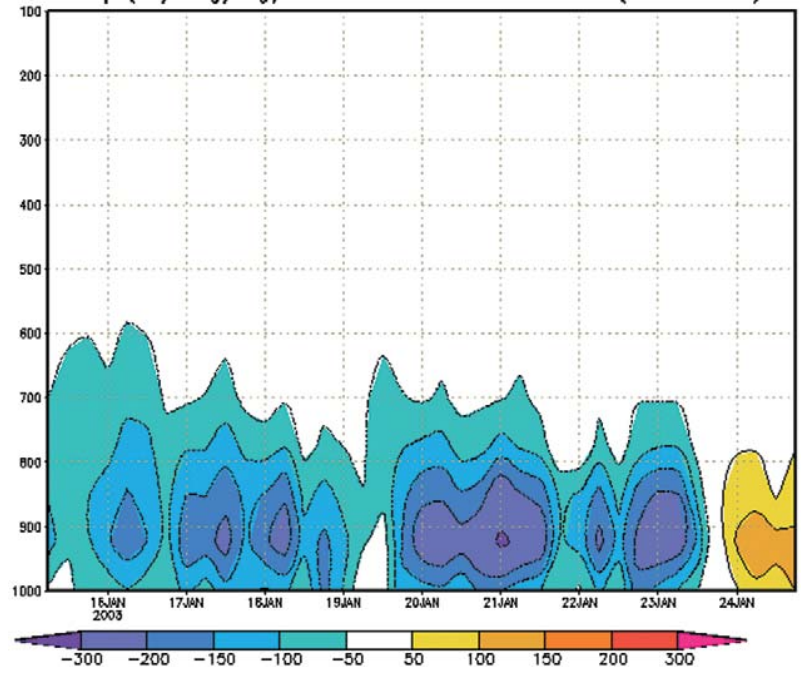

FIG. 14. (a) Upper-air stations included in the data assimilation experiments performed at CPTEC using GTS data only (NO-SALLJEX experiment) and GTS + SALLJEX observations (SALLJEX experiment); (b) meridional wind profile $\left(\mathrm{m} \mathrm{s}^{-1}\right)$ at Santa Cruz de la Sierra on $2 \mathrm{I}$ Jan 2003. Cross section of the meridional moisture transport along $17.5^{\circ} \mathrm{S}$ for (c) NO-SALLJEX and (d) SALLJEX experiments. Contour interval is $20 \mathrm{~g} \mathrm{~m}\left(\mathrm{~kg} \mathrm{~s}^{-1}\right)$.

of the westerlies, propagation of low-level wind bursts from the North Atlantic toward the La Plata basin, cold surges (southerly case), and synergism among the previous mechanisms. The studies will be carried out with a variety of model techniques, and SALLJEX observations will provide an important test for different model designs, predictability studies, and future observing systems. Additional questions that need to be addressed to assess the impact of SALLJEX include the following: i) Do SALLJEX data improve the un- derstanding of the water budget of the La Plata basin? Has the uncertainty of the LLJ moisture transport been reduced? ii) Does SALLJEX research improve the numerical model skill for predicting MCSs? Can we provide specific recommendations to the operational services on the data platforms that are necessary to provide information for data assimilation systems? It is expected that field campaigns implemented in the context of the VAMOS/LPB Program for the study of the La Plata basin hydroclimatology (information 
TABLE I. List of acronyms used in the text.

\begin{tabular}{|c|c|c|c|}
\hline ALLS & American Low-Level Jet Study & NCJE & No Chaco jet event \\
\hline ANPCYT & $\begin{array}{l}\text { Agencia Nacional de Promoción Científica y } \\
\text { Tecnológica }\end{array}$ & NOAA & $\begin{array}{l}\text { National Oceanic and Atmospheric } \\
\text { Administration }\end{array}$ \\
\hline BOP & Basic observation period & NOAA P-3 & NOAA Lockheed WP-3D Orion Aircraft \\
\hline CJE & Chaco jet events & NSF & National Science Foundation \\
\hline CLIVAR & Climate Variability and Prediction Program & NO-SALLJEX & $\begin{array}{l}\text { Data assimilation performed without } \\
\text { including SALLJEX data }\end{array}$ \\
\hline CNPq & $\begin{array}{l}\text { Conselho Nacional de Desenvolvimento } \\
\text { Científico e Tecnológico }\end{array}$ & OGP & Office of Global Programs \\
\hline CPTEC & $\begin{array}{l}\text { Centro de Previsão de Tempo e Estudos } \\
\text { Climáticos }\end{array}$ & PAOBS & Pibal balloon observation \\
\hline ENSO & El Niño-Southern Oscillation & PACS-SONET & $\begin{array}{l}\text { Pan American Climate Studies Sounding } \\
\text { Network }\end{array}$ \\
\hline ETA & “Step-mountain” Model & PICT & $\begin{array}{l}\text { Proyectos de Investigación Científica y } \\
\text { Technológica }\end{array}$ \\
\hline ERA & ECMWF Re-Analysis Database & PSAS & Physical-Space Statistical Analysis System \\
\hline FAPESP & $\begin{array}{l}\text { Fundação de Amparo à Pesquisa do Estado de } \\
\text { São Paulo }\end{array}$ & RAOBS & Radiosonde observations \\
\hline GCM & General circulation model & RAMS & Regional Atmospheric Modeling System \\
\hline ICPO & International CLIVAR Project Office & SACZ & South Atlantic convergence zone \\
\hline IGP & Instituto Geofísico del Perú & SALLJ & South American low-level jet \\
\hline IOP & Intensive observing period & SALLJEX & South American Low-Level Jet Experiment \\
\hline JOSS & Joint Office for Science Support & SENAMHI & $\begin{array}{l}\text { Servicio Nacional de Meteorología e } \\
\text { Hidrología del Perú }\end{array}$ \\
\hline LLJ & Low-level jet & SOP & Special observing period \\
\hline LPB & La Plata basin & SWG & Scientific working group \\
\hline MCS & Mesoscale convective systems & UBA & University of Buenos Aires \\
\hline MESA & Monsoon Experiment on South America & UCAR & $\begin{array}{l}\text { University Corporation for Atmospheric } \\
\text { Research }\end{array}$ \\
\hline MM5 & $\begin{array}{l}\text { Fifth-generation Pennsylvania State University } \\
\text { (PSU)-NCAR Mesoscale Model }\end{array}$ & VAMOS & $\begin{array}{l}\text { Variability of the America Monsoon } \\
\text { System }\end{array}$ \\
\hline NAL & Norwestern Argentinean low & WCRP & World Climate Research Program \\
\hline NCEP & National Centers for Environmental Prediction & & \\
\hline
\end{tabular}

online at www.joss.ucar.edu/platin) will address some of these issues.

ACKNOWLEDGMENTS. It is a pleasure to acknowledge the scientists, students, collaborators, and local volunteers that participated in the planning, execution, and data analysis effort for SALLJEX. The excellent support provided by C. Roberto Mechoso (former chair of the CLIVAR/ VAMOS Panel), Valery Detemmermann (WCRP), Michael Patterson (NOAA/OGP), and Carlos Ereño And Andreas Villwock (ICPO) is also highly appreciated.

SALLJEX was funded by NOAA/OGP,NSF (ATM0106776), and funding agencies from Brazil (FAPESP Grant 01/13816-1) and Argentina (ANPCYT PICT 07-06671, UBA 055). Part of the research work was undertaken with the support of the collaborative program IAI-CRN 55 and the Brazilian National Research Council (CNPq).

\section{APPENDIX: DATA ACCESS AND ARCHIVES.}

The development and maintenance of a comprehensive and accurate data archive is a critical step in meeting the scientific objectives of SALLJEX. A series of data management activities are supported under the VAMOS Programs Project Office at UCAR JOSS. The overall guiding philosophy for SALLJEX data management is to make the completed dataset available to the research community as soon as possible following the field campaign. The time periods for which data are 
archived cover the period from 1 November 2002 to 28 February 2003. SALLJEX data were collected from a variety of field activities. The SALLJEX data are available to the scientific community through a distributed archive coordinated by JOSS in Boulder, Colorado. The SALLJEX data management plan describes the guiding data management policies, the strategy and functional description of the data management systems, and the implementation details of the SALLJEX datasets and the data management systems. General information on the data activities ongoing in SALLJEX is available via the Internet. Access to specific SALLJEX datasets (sorted by various data categories) is provided via a "one stop" linkable master list of all datasets (information online at www.joss.ucar.edu/salljex/dm/ data_access_frame.html).

\section{REFERENCES}

Berbery, E. H., and E. Collini, 2000: Springtime precipitation and water vapor flux convergence over Southeastern South America. Mon. Wea. Rev., 128, 1328-1346.

Bonner, W. D., 1968: Climatology of the low level jet. Mon. Wea. Rev., 96, 833-850.

Byerle, L. A., and J. Paegle, 2002: Description of the seasonal cycle of low-level flows flanking the Andes and their interannual variability. Meteorologica, 27, 71-88.

Campetella, C., and C. Vera, 2002: The influence of the Andes Mountains on the South American lowlevel flow. Geophys. Res. Lett., 29, 1826, doi:10.1029/ 2002 GL015451.

Cavalcanti, I., and D. Herdies, 2004: Data assimilation study using SALLJEX data. CLIVAR Exchanges, Vol. 9, No. 1, International CLIVAR Project Office, 23-25.

—, and Coauthors, 2002: Climatological features represented by the CPTEC-COLA AGCM. J. Climate, 15, 2965-2988.

Douglas, M., M. Nicolini, and C. Saulo, 1999: The low level jet at Santa Cruz, Bolivia, during the JanuaryMarch 1998, pilot balloon observations and model comparison. Preprints, 10th Conf. on Global Change Studies, Dallas, TX, Amer. Meteor. Soc., 11-12.

Emmanuel, C. B., J. Meitin, and C. Ereño, 2004: The South America Low Level Jet Experiment [SALLJEX], Multinational logistics, coordination, and the implementation of the daily operations. CLIVAR Exchanges; Vol. 9; No. 1; International CLIVAR Project Office.

Garreaud, R. D., 1999: Multiscale analysis of the summertime precipitation over the central Andes. Mon. Wea. Rev., 127, 901-921.
Lichtenstein, E. R., 1980: The northwestern Argentina depression (in Spanish). Ph.D. dissertation, University of Buenos Aires, 223 pp.

Marengo, J., G. Fisch, I. Vendrame, I. Cervantes, and C. Morales, 2004a: On the diurnal and day-to-day variability of rainfall in Southwest Amazonia during the LBA-TRMM and LBA-WET AMC Campaigns of summer 1999. Acta Amazónica, 34, 593-503.

— - W. Soares, C. Saulo, and M. Nicolini 2004b: Climatology of the LLJ east of the Andes as derived from the NCEP reanalyses. J. Climate, 17, 2261-2280.

Nesbitt, S. W., and E. J. Zipser, 2003: The diurnal cycle of rainfall and convective intensity to three years of TRMM measurements. J. Climate, 16, 1456-1475.

Nicolini, M., C. Saulo, J. C. Torres, and P. Salio, 2002: Strong South American low-level jet events characterization during warm season and implications for enhanced precipitation, Meteorologica (Special Issue on South American Moonsoon System) 27, 59-69.

— , P. Salio, J. C. Torres, and E. J. Zipser, 2004a: The relationship between South American low level jet events with the formation and maintenance of mesoscale convective systems. 14th Int. Cont. on Clouds and Precipitation, Bologna, Italy, IAMAS/ International Commission on Clouds and Precipitation, 13-16.

—, _ G. Ulke, J. Marengo, M. Douglas, J. Paegle, and E. Zipser, 2004b: South American low-level jet diurnal cycle and three-dimensional structure. CLIVAR Exchanges, Vol. 9, No. 1, International CLIVAR Project Office, 6-9.

Paegle, J., C. D. Zhang, and D. B. Baumhefner, 1987: Atmospheric response to tropical thermal forcing in real data integrations. Mon. Wea. Rev., 115, 2975-2995.

—-, and Coauthors, 2004: Modeling studies related to SALLJEX. CLIVAR Exchanges, Vol. 9, International CLIVAR Project Office, 20-23.

Ropelewski, C. H., and S. Halpert, 1987: Global and regional scale precipitation patterns associated with the El Niño/Southern Oscillation. Mon. Wea. Rev., $115,1606-1626$.

Salio, P., M. Nicolini, and A. C. Saulo, 2002: Chaco low-level jet events characterization during the austral summer season. J. Geophys. Res., 107, 4816, doi:10.1029/2001JD001315.

Saulo, A. C., M. Nicolini, and S. C. Chou, 2000: Model characterization of the South American low-level flow during the 1997-1998 spring-summer season. Climate Dyn., 16, 867-881.

—, L. J. Ferreira, J. Mejia, and M. Seluchi, 2004a: Description of the thermal low characteristics using SALLJEX special observations. CLIVAR Exchanges, 
Vol. 9, No. 1, International CLIVAR Project Office, 9-11.

—, M. E. Seluchi, and M. Nicolini, 2004b: A case study of a Chaco low-level jet event. Mon. Wea. Rev., 132, 2669-2683.

Seluchi, M., A. Saulo, C. M. Nicolini, and P. Satyamurty, 2003: The northwestern Argentinean low: A study of two typical events. Mon. Wea. Rev., 131, 2361-2378.

Silva Dias, P. L., D. Moreira, and M. F. Silva Dias, 2001: Downscaling resolution and the moisture budget of the Plata Basin. IX Congreso Latinoamericano e Iberico de Meteorología y VIII Congreso Argentino de Meteorología. La Meteorología y el Medio Ambiente en el Siglo XXI, Buenos Aires, Argentina, Centro Argentino de Meteorológos, CD-ROM, 8.C.27-341.

Virji, H., 1981: A preliminary study of summertime tropospheric circulation patterns over South America estimated from cloud winds. Mon. Wea. Rev., 109, 599-610.

Xie, P., and P. A. Arkin, 1997: Global precipitation: A 17year monthly analysis based on gauge observations, satellite estimates, and numerical model outputs. Bull. Amer. Meteor. Soc., 78, 2539-2558.

Zipser, E., P. Salio, and M. Nicolini, 2004: Mesoscale convective systems activity during SALLJEX and the relationship with SALLJ events. CLIVAR Exchanges, Vol. 9, No. 1, International CLIVAR Project Office, 14-18. 